\title{
Publisher Correction: Predictive and reactive reward signals conveyed by climbing fiber inputs to cerebellar Purkinje cells
}

Dimitar Kostadinov (D), Maxime Beau (D), Marta Blanco-Pozo (D) and Michael Häusser (D)

Correction to: Nature Neuroscience https://doi.org/10.1038/s41593-019-0381-8, published online 29 April 2019.

In the version of this article initially published, author Marta Blanco-Pozo's surname was misspelled. The error has been corrected in the HTML and PDF versions of the article.

Published online: 24 January 2020

https://doi.org/10.1038/s41593-020-0594-X

๑ The Author(s), under exclusive licence to Springer Nature America, Inc. 2020 